\title{
ARCHAEOLOGICAL MATERIALS FROM CAVES \\ IN THE SOUTH CAUCASUS RECOVERED BY STEFAN KRUKOWSKI DURING HIS STAY IN GEORGIA 1916-1918
}

\author{
KAROL SZYMCZAK
}

A u t h o r's a d d r e s s: Faculty of Archaeology, University of Warsaw, Krakowskie Przedmieście 26/28, 00-927 Warszawa, Poland, e-mail: k.m.szymczak@uw.edu.pl, ORCID: 0000-0003-2735-3247

A b s t r a c t. The Polish archaeologist Stefan Krukowski stayed in Georgia from 1916 to 1918. During that time, apart from carrying out a comprehensive excavation in Gvarjilas Klde Cave, he also performed test digs in other Caucasian cave sites, the materials from which are still stored in the Georgian National Museum in Tbilisi but have never been published. In this paper these inventories are analysed and presented as a side note to a recently published book on the results of Krukowski's field research in Gvarjilas Klde.

K e y w o r d s: Georgia, Caucasus, Palaeolithic cave sites, Stefan Krukowski

\section{INTRODUCTION}

After almost a year of fighting on the eastern front of the First World War, on the $5^{\text {th }}$ of August 1915 the German army captured Warsaw, the capital city of the Kingdom of Poland (Vistula Land), fully integrated with Imperial Russia.

By that time Stefan Wincenty Krukowski, a young, twenty-five-year-old professional archaeologist interested mainly in the Stone Age was already associated with two institutions: the Erazm Majewski Archaeological Museum (formally until August 1913, although he maintained lively contacts later as well), and the Anthropological Workshop of the Warsaw Scientific Society, directed by Kazimierz Stołyhwo. The outbreak of the First World War made it impossible for Krukowski to continue his so far quite successful archaeological field investigations on the territories covered by the military operations, and it also put him at risk of being called up to the Russian Army. In that situation, as early as June 1915, he came forward with a request to the Józef Mianowski Fund (Foundation for the Promotion of Science) for a scholarship which would enable him to conduct an archaeological excavation of the Palaeolithic site of Kostenki (today in Voronezh Oblast, SW Russia). The choice of this particular site 
was not accidental; the site was already known from publications by I. S. POLYAKOv (1880), and in Warsaw also from the collection of N. I. Krysztafowicz (the labels dated from 1902). Within less than 10 days, Krukowski, supported by his two principals, E. Majewski and K. Stowyhło, obtained a quite generous scholarship of 900 rubles.

The excavation planned in Kostenki was carried out between July and September 1915 and was successfully completed at the expense of 300 rubles. The artefacts recovered during this campaign never reached Warsaw, but the documentation, together with Krukowski's diary and his notes concerning his studies on the lithic industry, have survived to this day.

It is not clear today why, after finishing his field work in Kostenki and making a trip to Baku (Azerbaijan), S. Krukowski found himself in Georgia at the beginning of 1916. It seems possible that in the meantime he was conscripted into the Russian army, and then, as an archaeologist, was posted by his command to the Caucasian Museum in Tifilis (present Tbilisi) to carry out the field investigation. Indeed, he undertook archaeological excavations in a number of caves in the Georgian Caucasus, which, according to his handwritten diary, happened during the 1916 and 1917 seasons. His greatest achievement in that period was the excavation of the Gvarjilas Klde Cave, where he unearthed very rich, well-stratified assemblages of Upper Palaeolithic artefacts, which have recently become the subject of a separate monograph (Кот et al. 2019). The materials from the remaining cave sites explored by Krukowski have not been published as yet, even though they remain safely stored in the Georgian National Museum in Tbilisi. Thanks to the kindness of Prof. Dr. David O. Lordkipanidze, the General Director of the Georgian National Museum, and Dr. Nino Jakeli, the Scientific Secretary and Curator of Stone Age Collections of the same museum, the author was allowed to study these artefacts and present them in this paper. The value of the reviewed data goes beyond the history of archaeology, as they can still offer some additional clues useful for planning future Stone Age field projects in the Caucasus region.

\section{THE MATERIALS}

Apart from the Gvardjilas Klde Cave mentioned above, the handwritten labels in the collection of the Georgian National Museum contain references to at least six more Caucasian caves investigated by Krukowski (Map 1):

I. Taro Klde Cave,

II. Khergulis Klde Cave,

IIa. Vachevi (the village where Khergulis Klde Cave is located),

III. Sadzrokhia Cave,

IV. Sakajia Cave,

IVa. Motsameta (the name of the monastery in the vicinity of the Sakajia Klde Cave),

V. Sachinkia Cave,

VI. Cheltis Tavi Cave,

VIa. Gundaeti (the village where Cheltis Tavi Cave is located). 


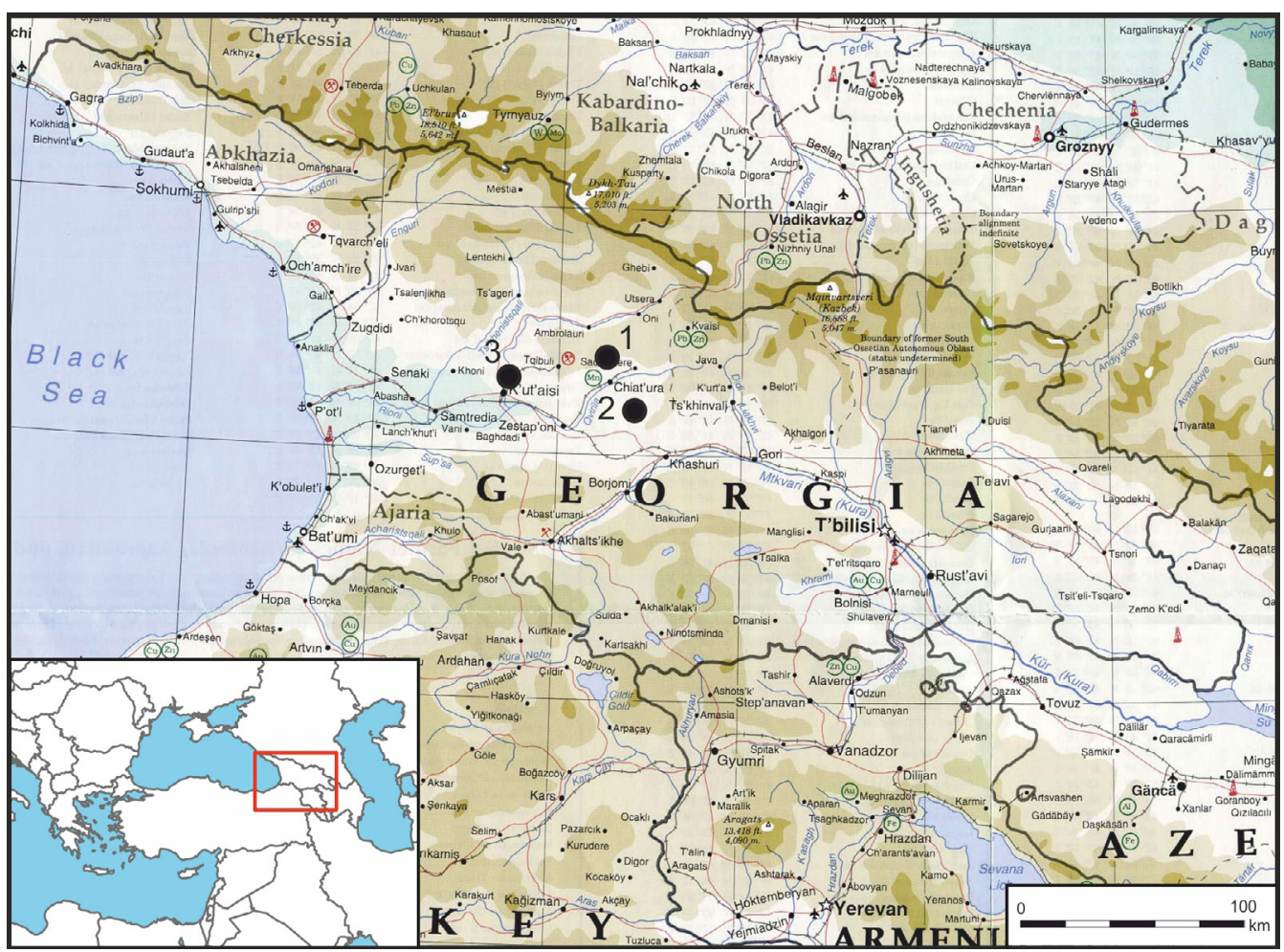

Map 1. Location of the sites discussed in the text: 1 - Gvarjilas Klde, Taro Klde, Khergulis Klde (Vachevi); 2 - Sadzrokhia Klde, Sachinka Cave, Cheltis Tavi Cave (Gundaeti); 3 - Sakajia Klde (Motsameta). Base map from: https://upload.wikimedia.org/wikipedia/commons/9/98/Caucasus region 1994.jpg

\section{Taro Klde Cave}

The test trench yielded quite numerous, though apparently mechanically mixed-up inventory of lithic and organic finds, containing Middle and Upper Palaeolithic elements.

Flint artefacts:

a) Middle Palaeolithic

- 3 typical, quite regular, triangular, retouched points of Mousterian type; two of them have distinctly naturally glazed surfaces (Fig. 1: 1),

- massive bifacial backed knife, with both faces cortical, naturally sharpened, very regular, slightly crushed (Fig. 1:2).

b) Upper Palaeolithic

- some 80 cores and core forms, mostly for blades, quite regular; many with doubled striking platforms (Fig. 1: 3,4); noteworthy is the tendency to form an acute core angle on one platform, and an angle close to the right one on the opposite platform, which possibly suggests the use of the preferential blade knapping technique; no pressure technique noted,

- over 1500 flakes, mostly fine and very fine,

- a technical spall - a very regular apical/overshot blade from a blade core (Fig. 1: 5), 
- over 500 blades and their broken fragments, mostly very regular, some finely retouched (Fig. 1: 6, 7),

- a bifacial saw-like tool with very regular, delicate, perfectly shaped retouch; a chronology younger than Upper Palaeolithic cannot be excluded (Fig. 1: 8).

The prevailing raw material is reddish/pinky flint with frequent white dots; most of the finds is covered with a very heavy, secondary calcium carbonate crust.

Other finds:

- regular bifacial stone disc (61 $\mathrm{mm}$ in diameter),

- approx. half a dozen heavily weathered pieces of stone (granite, cinder, etc.),

- a fragment of a grinding slab or of a quern made of volcanic rock; traces of polishing distinctly visible,

- a dozen of bone fragments; 3 or 4 with the traces of intentional modification (1 regular awl).

\section{Khergulis Klde Cave}

The trench produced quite a large assemblage representing, as it seems, the Middle Palaeolithic, as well as the Upper Palaeolithic Gravettian industry, with some later (Neolithic, Bronze Age, and modern times) admixtures.

Flint artefacts:

a) Middle Palaeolithic

- half a dozen of massive flakes with heavily naturally glazed surfaces,

- a triangular point of Mousterian type,

- 11 side scrapers; generally massive but including 3 finer forms; distinct retouch on at least one of the edges (Fig. 2: 1).

b) Upper Palaeolithic

- about 75 cores and core forms, mostly for blade production, with single, as well as doubled striking platforms; fine (less than $50 \mathrm{~mm}$ ) and very fine items present,

- some 150 fine and very fine irregular flakes, including in that number 2 obsidian scales,

- some 150 fine, regular bladelets, a few of them naturally glazed,

- 12 retouched flakes,

- 2 retouched and micro-retouched regular blades,

- a dozen or so technical spalls (trimming blades, apical/overshot blades, etc.),

- 9 end scrapers; blade (Fig. 2: 2, 3), and flake (single rounded - Fig. 2: 4, and another fan-like) implements present,

- 8 burins: a dihedral, straight implement (Fig. 2: 5), a sided burin, two sided burins on regular obsidian blades, four other burin forms,

- an extremely regular combined tool, with a straight perforator on the one end, and an arched, slightly splintered end-scraper on the opposite end (Fig. 2: 6),

- 4 perforators; 1 obsidian perforator on blade with coarse, irregular retouch on one of the edges, a top fragment of a blade perforator (Fig. 2: 7), a microlithic perforator (drill) with blunting, inverse retouch (Fig. 2: 8), and a blade perforator with delicate but distinct doubled stings on both ends (Fig. 2: 9), 

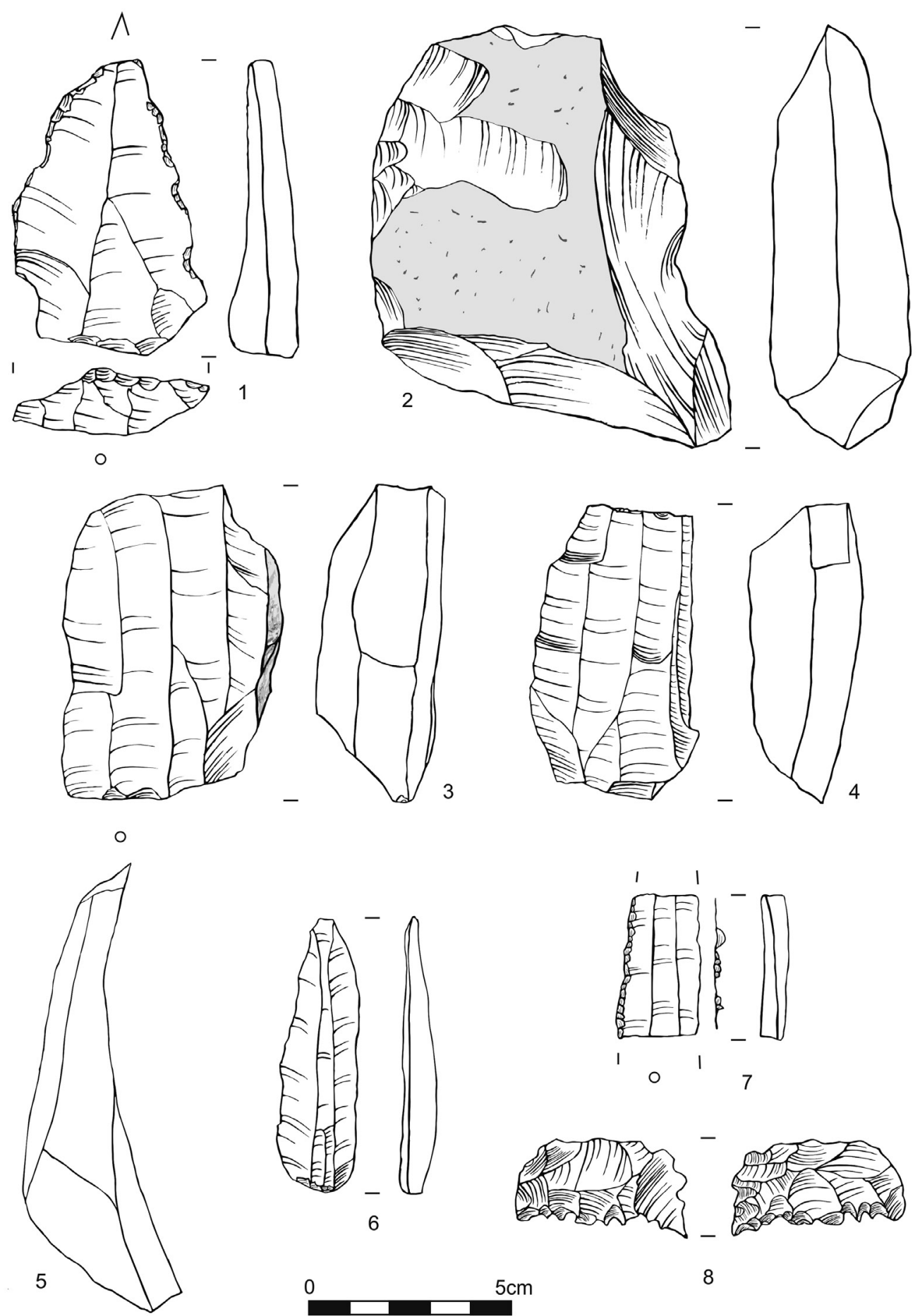

Fig. 1. Taro Klde: 1 - triangular point; 2 - bifacial backed knife; 3, 4- blade cores; 5 - technical spall; 6 - blade; 7 - finely retouched blade; 8 - saw-like implement 

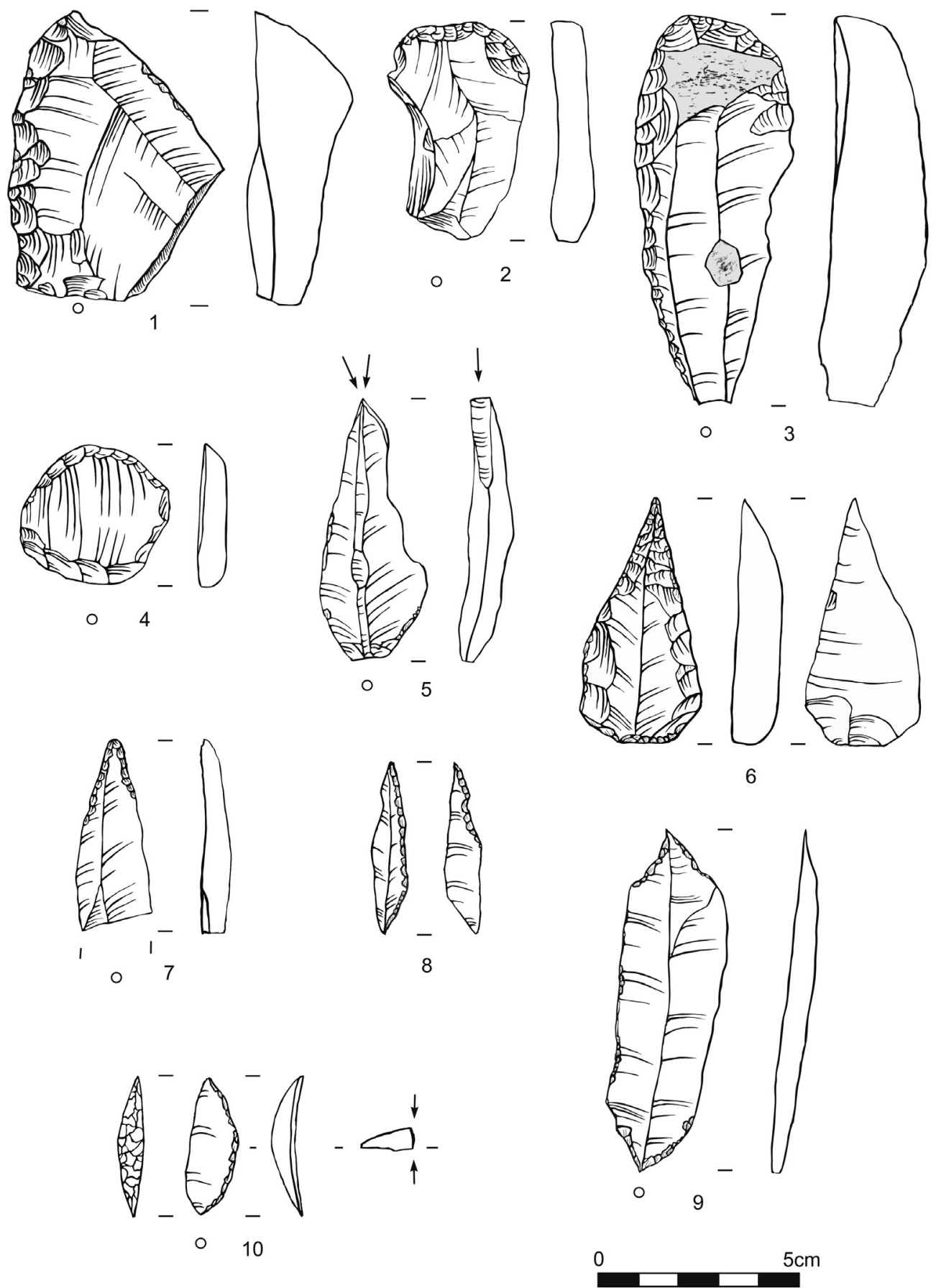

Fig. 2. Khergulis Klde: 1 - side scraper; 2, 3, 4 - end scrapers; 5 - burin; 6 - combined tool (perforator + end scraper); 7, 8, 9 - perforators; 10 - arched backed piece 
- ideal arched back piece (crescent, segment) with blunting, bilateral retouch (Fig. 2: 10).

c) Neolithic/Bronze Age

- regular triangular flint point with a notched base, formed with precise, flat surface retouch.

Other artefacts (Neolithic/Bronze Age/modern times):

- ceramic spindle whorl with flat and convex faces,

- fragment of an ornamented bone pipe,

- 6 clods of cherry-red mineral dye (ochre).

IIa. Vachevi (Khergulis Klde Cave)

Only 6 fragments of prehistoric pottery were recorded.

\section{Sadzrokhia Cave}

The dig yielded some Middle and Upper Palaeolithic (Gravettian) artefacts, accompanied by modern finds.

Flint artefacts:

a) Middle Palaeolithic

- 9 relatively massive, distinctly glazed flakes,

- 2 triangular points of Mousterian type, also glazed.

b) Upper Palaeolithic

- 7 cores and core forms, included in that number 5 blade items with double striking platforms,

- more than 200 fine and very fine irregular flakes,

- more than 200 fine and very fine blades and bladelets, mostly broken,

- 59 medial parts of finely, regularly retouched blades,

- a perfect, relatively massive, straight dihedral burin on a blade, with multiplied blows, doubled on both ends (Fig 3: 1),

- a top fragment of a massive blade perforator (Fig. 3: 2),

- a medial part of a Gravettian backed piece (point?) with blunting, one-sided retouch (Fig. 3: 3).

Other finds:

- an oval, well-rounded, worked pebble,

- dozens of animal bone fragments (1 fragment of a mandible).

Some pieces of modern pottery and bone remains were also found.

\section{Sakajia Cave}

The test trench produced poor Upper Palaeolithic flint, rock, and bone material, accompanied by modern-period pottery fragments.

Flint artefacts:

- 9 cores and core forms; including in that number 5 regular blade items with double striking platforms; the angle of the main platform is usually acute, and of 

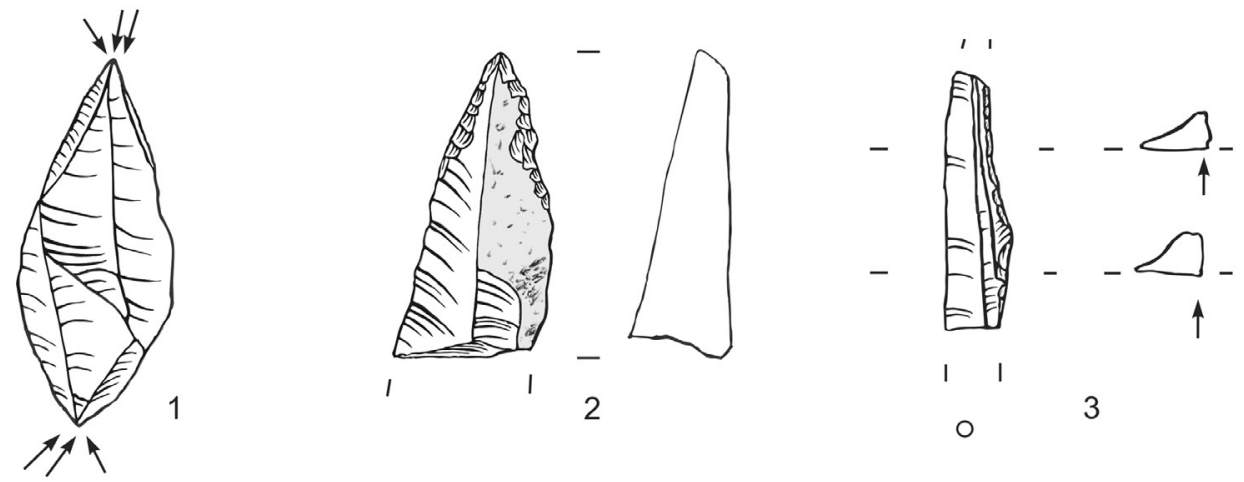

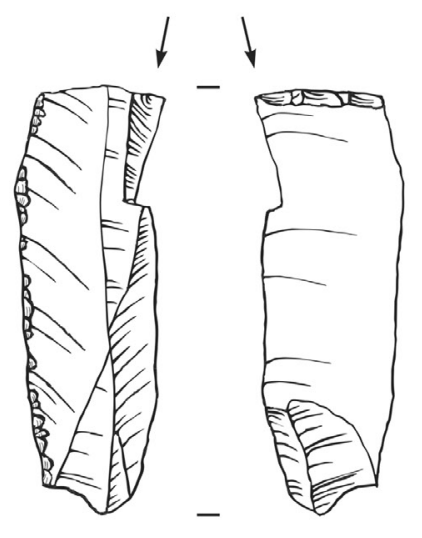

4

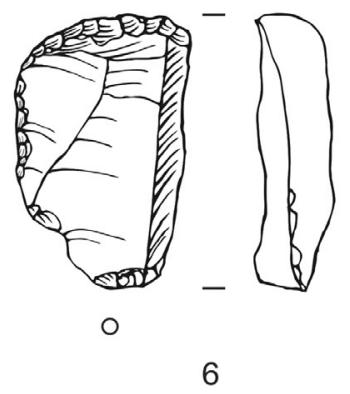

5
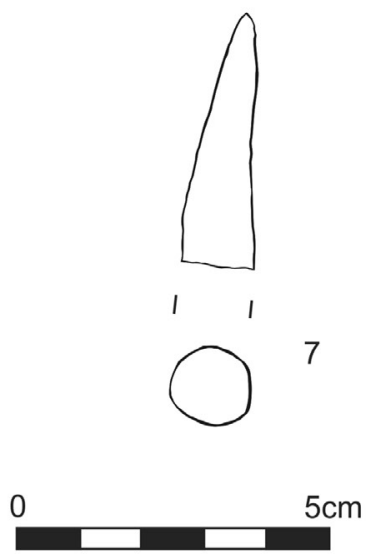

Fig. 3. Sadzrokhia Cave: 1 - burin; 2 - perforator; 3 - backed piece. Sakajia Klde: 4, 5 - burins; 6 - end scraper; 7 - tip of a bone point 
the opposite, correctional, close to the right; the remaining 4 are fine, irregular cores from small, yellowish, well-rounded flint nodules,

- 2 massive, coarse, hinged flakes,

- 35 flakes, blades and their fragments, most probably coming from one core,

- 7 obscure, massive burin forms; including in that number a formally sided burin on truncation from an obsidian blade insert with a micro-retouched edge, splintered on both ends (Fig. 3: 4).

Other finds:

- 2 heavily burnt out flakes,

- some 100 fine animal bone and tooth fragments,

- modern pottery sherds.

IVa. Motsameta (Sakajia Cave)

Selected pieces from the surface collection are stored in the museum:

- 4 obsidian bladelets,

- an end scraper on elongated flake with the left edge retouched (Fig. 3: 6),

- a fine truncated piece, multiplied, sided burin on truncation from a relatively massive, irregular, cortical blade (Fig. 3: 5),

- a broken off tip of a delicate, carefully polished bone point of circular section (Fig. 3: 7).

The general character of the finds suggests their Upper Palaeolithic provenience.

\section{Sachinkia Cave}

Traces of prehistoric, as well as historic occupation were recorded.

- 8 fine, irregular flakes, including in that number 2 obsidian pieces,

- 6 fine, regular blade fragments,

- 8 modern pottery sherds.

VI. Cheltis Tavi Cave

Some mixed prehistoric and modern-day material was collected, probably from the surface.

- some 200 various flakes, fine to quite massive,

- a regular bladelet,

- a regular burin spall,

- a number of modern-day pottery sherds,

- a blade of an iron knife.

VIa. Gundaeti (Cheltis Tavi Cave)

Only some mammal and bird remains were noticed; including several micro fauna bones. 


\section{FINAL REMARKS}

From the overview presented above it emerges that if a certain cave had been inhabited during the Palaeolithic, we can count on a (stratigraphic, if preserved) sequence of the late Middle (Mousterian) and Upper (Early and/or Late Gravettian) Palaeolithic stone and bone material (KozŁowsKi 1970, 1972, 1998; TUSHABRAMISHVili et al. 2002; Meshveliani et al. 2004; Bar Yosef et al. 2006, Pinhasi R. et al. 2011). Such a situation, sometimes also including Early Upper Palaeolithic (Aurignacian) layers, is known from many other archaeologically excavated Caucasian caves and rock shelters, like Ortvale Klde (Tushabramishvili et al. 1999, 2002; AdLER et al. 2008), Bondi Cave (Tushabramishvili et al. 2012; Pleurdeau et al. 2016), Dzudzuana Cave (Bar-Yosef et al. 2011; Margherita et al. 2017), Satsurblia Cave (Pinhasi et al. 2014), Gvarjilas Klde Cave (Krukowski 1916; KozlowsKi 1972), etc. The latest phases of the Upper Palaeolithic are represented in Deviss Khverli (Nioradze, OtTe 2000). Traces of later prehistoric settlement (Neolithic, Bronze or Iron Age) are rather rare, while sometimes the activity dated from the historic and modern-day periods could be noted.

Lithic raw materials used in certain sites under discussion, including the items produced of easily recognizable obsidian, seem to be quite differentiated, especially in terms of colour. In many cases a characteristic secondary patina (natural smoothing, glazing, and rounding of the edges and inter-negative scars, with frequent change of the primary colour into white) allow older, Middle Palaeolithic artefacts to be distinguished from younger, Upper Palaeolithic, Mesolithic and Neolithic ones.

From the typological point of view the materials described above fit quite well into the recently elaborated Middle and Upper Palaeolithic sequences from the Caucasus.

It should be mentioned that further archaeological field research was conducted in Sakajia Cave (G. Nioriadze 1936-1937; M. NioriadZE 1974-1980), as well as in Khergulis Klde Cave (N. Bedzenishvili, G. Dochanashvili 1967-1973). In Sakaljia Cave Neanderthal bone remains were found, and samples taken from the freshly cleaned cross section are now undergoing laboratory analyses and dating (N. Jakeli's personal communication). The Sadzrokhia, Sachinkia, and Celtis Tavi Caves were also visited and test excavated by a team led by D. TusHABRAMISHVILI (1972-1973), but with no encouraging results. At present the exact location of Taro Klde remains unknown.

The presented materials offer a partial overview of the initial stages of the archaeological field work and its results on the Palaeolithic sites in Georgia, showing at the same time the significant role played by the Polish archaeologist Stefan Krukowski in that research.

ACKNOwLEDGEMENTs. The research received financial support from the Foundation of the Historical Faculty of the University of Warsaw 'VARIA' and the Krukowski Georgian-Polish Interdisciplinary Research Center in Kutaisi, while organizational help was offered by the Embassy of the Republic of Poland, and the Polish Institute in Tbilisi; I would also like to express my special gratitude to Dr. Nino Jakeli for making detailed information on particular sites available, as well as for improving the English transliteration of local names. 


\section{REFERENCES}

Adler D.S., Bar-Yosef O., Belfer-Cohen A., Tushabramishvili N., Boaretto E., Mercier N., ValLADAS H., RINK W. J., 2008. Dating the demise: Neandertal extinction and the establishment of modern humans in the southern Caucasus. Journal of Human Evolution 55: 817-833.

Bar Yosef O., Belfer-Cohen A., Adler D. S., 2006. The Implications of the Middle-Upper Paleolithic Chronological Boundary in the Caucasus to Eurasian Prehistory. Anthropologie XLIV/1: 49-60.

Bar-Yosef O., Belfer-Cohen A., Mesheviliani T., Jakeli N., Bar-Oz G., Boaretto E., Goldberg, P. Kvavadze E., Matskevich Z., 2011. Dzudzuana: an Upper Palaeolithic cave site in the Caucasus foothills (Georgia). Antiquity 85: 331-349.

Kot M., Brzeziński W., Jackeli N., KozŁowski S. K., SzymczaK K., Otcherednoy A., TushabramiSHVILI N., KARASIEWICZ-SzCZYPIORSKi R., (Eds), 2019. Jaskinia Gvardjilas Klde w Gruzji. Opracowanie wydane w stulecie badań polskiego archeologa Stefana Krukowskiego (Gvardjilas Klde Cave in Georgia. Celebrating the Centenial of Polish Archaeologist Stefan Krukowski's Research). Warszawa: Państwowe Muzeum Archeologiczne w Warszawie, Wydawnictwa Uniwersytetu Warszawskiego (in Russian, Polish, Georgian and English).

KozŁowski J. K., 1970. Górny paleolit w krajach zakaukaskich i na Bliskim Wschodzie, cz. I, Geochronologia i zagadnienia początków górnego paleolitu. Prace Komisji Archeologicznej Oddziału PAN 9: $121-142$.

Kozıowski J. K., 1972. Górny paleolit w krajach zakaukaskich i na Bliskim Wschodzie, cz. II, Periodyzacja górnego paleolitu zachodnich krajów zakaukaskich. Światowit 33: 7-47.

Kozlowski J. K., 1998. The Middle and the Early Upper Palaeolithic around the Black Sea. In: T. Akazawa, K. Aoki, O. Bar-Yosef (Eds), Neanderthals and Modern Humans in Western Asia. New York, Plenum Press: 461-482.

KRUKowski S., 1916. Peshchera Gvardzhilas-klde v Rgani. Izvestya Kavkazkogo Muzeya 1.10: 253-259 (after: Kozłowski J. K. 1972, 7).

Margherita C., Oxilia G., Barbi V., Panetta D., Hublin J.-J., Lordkipanidze D., Meshveliani T., Jakeli N., Matskevich Z., Bar-Yosef O., Belfer-Cohen A., Pinhasi R., Benazzi S., 2017. Morphological description and morphometric analyses of the Upper Palaeolithic human remains from Dzudzuana and Satsurblia caves, western Georgia. Journal of Human Evolution 113: 83-90.

Meshyeliani T., Bar-Yosef O., Belfer-Cohen A., 2004. The Upper Paleolithic in western Georgia. In: P. J. Brantingham, S. L. Kuhn, K. W. Kerry (Eds), The Early Upper Paleolithic beyond Western Europe. Berkeley, Los Angeles, London. University of California Press: 129-143.

Nioradze M. G., Otte M., 2000. Paleolithique superieur de Georgie. L'Anthropologie 104: 265-300.

Pinhasi R., Meshveliani T., Matskevich Z., Bar-Oz G., Weissbrod L., Miller C. E., Wilkinson K., Lordkipanidze D., Jakeli N., Kvavadze E., Higham T. F. G., Belfer-Cohen A., 2014. Satsurblia: New Insights of Human Response and Survival across the Last Glacial Maximum in the Southern Caucasus. PLoS ONE 9(10): 1-16.

Pinhasi R., Higham T. F. G., Golovanova L. V., Doronichev V. B., 2011. Revised age of late Neanderthal occupation and the end of the Middle Paleolithic in the northern Caucasus. Proceedings of the National Academy of Sciences of the United States of America. PNAS 108(21): 8611-8616.

Pleurdeau D., Moncel M.-H., Pinhasi R., Yeshurun R., Higham T., Agapishvili T., Bokeria M., Muskhelishvili A., Le Bourdonnec F.-X., Nomade S., Poupeau G., Bocherens H., Frouin M., Genty D., Pierre M., Pons-Branchu E., Lordkipanidze D., Tushabramishvili N., 2016. Bondi Cave and the Middle-Upper Palaeolithic transition in western Georgia (south Caucasus). Quaternary Science Reviews 146: 77-98. 
Tushabramisbvili N., Lordkipanidze D., Vekua A., Tvalcherlidze M., Muskhelishvili A., Adler D. S., 1999. The Palaeolithic Rockshelter of Ortvale Klde, Imereti Region, the Georgian Republic. Prehistorie \&tropeenne 15: 65-77.

Tushabramishvili N., Adler D. S., Bar-Yosef O., Belfer-Cohen A., 2002. Current Middle \& Upper Palaeolithic research in the southern Caucasus. Antiquity 76: 927-928.

Tushabramishvili N., Pleurdeau D., Moncel M.-H., Agapishvili T., Vekua A., Bukhsianidze M., Maureille B., Muskhelishvili A., Mshvildadze M., Kapanadze N., Lordkipanidze D., 2012. Human remains from a new Upper Pleistocene sequence in Bondi Cave (Western Georgia). Journal of Human Evolution 62: 179-185. 